\title{
Pengaruh Kredit Usaha Tani Terhadap Kesejahteraan Petani di Desa Kedung Lengkong, Kecamatan Dlangu, Kabupaten Mojokerto
}

\section{The Effect of Agricultural Credit on Farmers' Welfare in Kedung Lengkong Village, Dlangu District, Mojokerto Regency}

\author{
Heri Susanto $^{1}$, Ramon Syahrial ${ }^{2}$, Adi Budiwan ${ }^{3}$ \\ ${ }^{1,2,3}$ Program Studi Agribisis Fakultas Pertanian \\ Universitas Wijaya Putra Surabaya
}

\section{ARTICLE INFO}

Article history:

DOI:

10.30595/pspfs.v2i.195

Submitted:

July 29, 2021

Accepted:

Sept 10, 2021

Published:

Nov 10, 2021

Keywords:

Agricultural Credit, Welfare, Income

\begin{abstract}
Suppose the agricultural sector is supported by a comprehensive and sustainable planning system and balanced with an adequate budget (such as capital). In that case, the role of the agricultural sector will be optimal. Farmers face the problem of funding; although many farmers can increase their yields, they cannot develop their own farming business if they do not have sufficient funds. Therefore, farmers will apply for loans from formal and informal financial institutions to overcome the lack of funds. However, credit growth has increased, especially in the agricultural sector, which is the agricultural sector where the government plans to improve the rural economy. Agricultural credit plays a crucial role in developing agriculture to obtain higher yields. If output increases, farmers' income will also increase, which will benefit farmers. The research method used was quantitative, with a sample of 100 people. This study used a population of 187 farmers in Kedung Lengkong Village, Dlangu District, Mojokerto Regency. The analysis used in this study was simple regression to understand the impact of credit availability on farmers' welfare. The hypothesis test results were that credit has a positive effect on welfare, with a regression coefficient value of 0.291. Credit helped farmers purchase fertilizers, seeds, and other things related to the need for farming so that the agricultural production process could run according to planning so that production results were in line with farmers' expectations to increase profits. These profits, in the end, became a source to meet the costs of meeting basic needs. The ability to meet these needs raised the standard of living and the community's welfare so that people could have a better quality of life.
\end{abstract}

This work is licensed under a Creative Commons Attribution 4.0 International License.

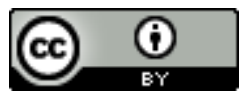

Corresponding Author:

Heri Susanto

Program Studi Agribisis Fakultas Pertanian

Universitas Wijaya Putra Surabaya

Email: herisusanto@uwp.ac.id

\section{PENDAHULUAN}

Indonesia merupakan negara agraris, dengan sebagian besar petaninya merupakan petani kecil yang memiliki lahan pertanian kecil, sehingga dari usaha taninya tidak dapat mencukupi kebutuhan hidupnya. Guna 
hal tersebut pemerintah mempunyai kewajiban, bagaimana meningkatkan produktifitas hasil pertanian guna menopang pembangunan ekonomi dan industri berbasis pertanian khususnya bagi pada pertanian dengan kategori pertanian kecil. Beberapa faktor dari rendahnya produktivitas usahatani antara lain keterbatasan lahan, pengetahuan yang dimiliki oleh petani, kurangnya modal untuk pembelian sarana produksi terutama untuk pembelian benih, pupuk dan obat-obatan yang harganya semakin lama semakin tinggi.

Pembiayaan pertanian merupakan salah satu komponen penting dalam upaya pengembangan sektor pertanian disisi lain perhatian perbankan terhadap sektor pertanian sangatlah rendah pihak perbankan cenderung lebih memperhatikan sektor non pertanian, hal ini antara lain disebabkan karena usaha di sektor pertanian mempunyai risiko yang tinggi dan perputaran uang yang lambat.

Pedagang pengumpul merupakan sumber pembiayaan informal yang sebagian besar dimanfaatkan oleh petani. Namun, pihak penyedia kredit informal, yaitu pedagang hasil memberikan pinjaman kredit dengan tujuan selain mendapatkan keuntungan ekonomi juga untuk mengikat petani agar secara tidak langsung petani akan menjual hasil panen kepada mereka sehingga menjadikan petani tidak bisa menentukan hasil penjualan pada pedagang yang mau membeli dengan harga yang lebih tinggi. Hal ini menunjukkan ketersediaan modal (kredit) baik yang berasal dari lembaga formal maupun informal merupakan komponen yang penting bagi kelangsungan usaha tani.

Beberapa hasil peneltian menunjukkan bahwa aksesibilitas sebagian besar petani terhadap sumber kredit formal masih sangat terbatas (Anggraeni, 2009; Nurmanaf et al. 2006; Weber dan Musshoff, 2012; Yehuala, 2008). Dapat dikatakan pentingnya ketersediaan kredit bagi petani ternyata belum didukung sepenuhnya oleh keberadaan sumber pembiayaan khususnya dari lembaga formal. Khusus untuk komoditas perkebunan dengan jenis tanaman tahunan, (Anggraeni, 2009) menyebutkan bahwa petani kelapa di Indragiri Hilir Provinsi Riau mayoritas akses pada keuangan informal, yaitu pedagang China yang membeli hasil produksi para petani dalam bentuk kopra.

Hal ini mendasari pentingnya dilakukan penelitian untuk melihat bagaimana akses petani terhadap kredit yang ada dengan mengakaji lebih lanjut faktor-faktor yang memengaruhi aksesibilitas petani. Selain itu pemberian kredit sebagai tambahan modal diharapkan akan membantu petani untuk mengembangkan usahanya dan sekaligus dapat berdampak pada peningkatan pendapatan melalui peningkatan produksi sehingga dapat meningkatkan kesejahteraan petani.

\section{METODE PENELITIAN}

Penelitian ini adalah jenis penelitian verivikatif atau uji hipotesis yaitu penelitian yang menjelaskan dan mencari hubungan sebab akibat antara variabel kredit dan variabel kesejahteraan masyarakat di Desa Kedung Lengkong, Kecamatan Dlangu, Kabupaten Mojokerto.

Adapun yang menjadi populasi dalam penelitian ini adalah petani di Desa Kedung Lengkong, Kecamatan Dlangu, Kabupaten Mojokerto. Dalam menentukan sampel dalam penelitian ini menggunakan rumus Slovin, hal ini karena peneliti tidak mengetahui secara pasti perilaku dari populasi penelitian. Dengan rumus:

$$
\begin{aligned}
& n=\frac{\mathrm{N}}{1+\mathrm{N}(\mathrm{e})^{2}} \\
& \text { Keterangan: } \\
& \mathrm{N}=\text { Populasi } \\
& \mathrm{n}=\text { sampel } \\
& \mathrm{e}=\text { margin error }
\end{aligned}
$$

Dengan tingkat kepercayaan 90\%, maka tingkat kesalahan adalah 10\%. Sehingga peneliti dapat menentukan batas minimal sampel yang dapat memenuhi syarat margin of error $10 \%$ dengan memasukkan margin error tersebut ke dalam formula atau rumus Slovin.

Berdasarkan notasi rumus besar sampel penelitian minimal oleh Slovin diatas, maka dengan total populasi 187 orang, maka bisa tentukan minimal sampel yang akan diteliti dengan perhitungan sebagai berikut:

$$
\begin{aligned}
& \mathrm{n}=\mathrm{N} /\left(1+\left({\mathrm{N} \times \mathrm{e}^{2}}^{2}\right)\right) \\
& \text { sehingga: } \\
& \mathrm{n}=187 /\left(1+\left(187 \times 0,1^{2}\right)\right)
\end{aligned}
$$




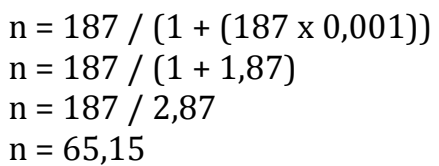

Apabila dibulatkan maka besar sampel minimal dari 187 populasi pada margin of error $10 \%$ adalah sebesar 65,15 yang kemudian digenapkan menjadi 65 orang. Namun dalam penelitian ini peneliti mengambil sampel 100 orang sehingga tidak terlalu dekat dengan batas minimal sampel.

Analisis data guna pengujian hipotesis peneliti menggunakan statistik parametris. Adapun teknik yang dipakai untuk menguji hipotesis adalah dengan menggunakan rumus korelasi Product Moment, persamaan regresi untuk membuktikan kebenaran hipotesis.

Mengenai kriteria atau skor menurut Sugiono (2009:110) masing-masing penelitian ada yang menggunakan jenjang $3(1,2,3)$, jenjang $5(1,2,3,4,5)$ dan jenjang $7(1,2,3,4,5,6,7)$. Selanjutnya untuk menghitung hubungan antara variabel bebas dan variabel terikat digunakan analisis koefisien korelasi dengan rumus korelasi product moment sebagai berikut:

$$
\mathrm{r}=\frac{\mathrm{n} \sum \mathrm{xy}-\left(\sum \mathrm{x}\right) \cdot\left(\sum \mathrm{y}\right)}{\left.\sqrt{\left\{\mathrm{n} \sum \mathrm{X}^{2}\right.}-\left(\sum \mathrm{X}\right)^{2}\right\}\left\{\mathrm{n} \sum \mathrm{Y}^{2}-\left(\sum \mathrm{Y}\right)^{2}\right\}}
$$

(Sugiyono, 2012:183)

dimana:

rxy = Koefisien korelasi antara X dan Y

$\mathrm{X}=$ Variabel Bebas

$\mathrm{Y}=$ Variabel Terikat

Dimana nilai "r" atau koefisien korelasi yang dihasilkan oleh rumus, mempunyai arti sebagai berikut.

Tabel 2: Pedoman Untuk Memberikan Interpretasi Koefisien Korelasi

\begin{tabular}{cl}
\hline Interval Koefisien & Tingkat Hubungan \\
\hline $0,00-0,199$ & Sangat Rendah \\
$0,20-0,399$ & Rendah \\
$0,40-0,599$ & Sedang \\
$0,60-0,799$ & Kuat \\
$0,80-1,000$ & Sangat Kuat \\
\hline
\end{tabular}

(Sugiyono, 2003: 216)

Kemudian untuk menguji hipotesis dalam penelitian ini digunakan analisis regresi Linear sederhana. Adapun langkah-langkah yang digunakan dalam analisis ini antara lain:

$\mathrm{Y}=\mathrm{a}+\mathrm{bX}$

(Sugiyono, 2012:188)

Selanjutnya untuk mengetahui nilai konstanta dan nilai koefisien regresi menggunakan:

$$
\begin{aligned}
& \mathrm{a}=\frac{\sum \mathrm{Y}-\mathrm{b}\left(\sum \mathrm{x}\right)}{\mathrm{n}} \\
& \mathrm{b}=\frac{\mathrm{n}\left(\sum \mathrm{XY}\right)-\left(\sum \mathrm{x}\right)\left(\sum \mathrm{Y}\right)}{\mathrm{n}\left(\sum \mathrm{X}^{2}\right)-\left(\sum \mathrm{X}\right)^{2}}
\end{aligned}
$$

\section{Keterangan:}

$\mathrm{x}=$ Variabel bebas

$\mathrm{a}=$ Konstanta

$\mathrm{b}=$ Koefisien regresi

Selanjutnya untuk melihat pengaruh tersebut dengan mengetahui nilai koefisien regresi (b). Nilai tersebut digunakan sebagai dasar pengambilan keputusan untuk menerima atau menolak hipotesis yang diajukan. Adapun kesimpulan yang dapat diambil adalah sebagai berikut: 
$\mathrm{H}_{0}$ : Tidak terdapat pengaruh efektivitas kredit terhadap kesejahteraan petani.

$\mathrm{H}_{1}$ : Terdapat pengaruh kredit terhadap kesejahteraan petani

\section{HASIL DAN PEMBAHASAN}

Sumber-sumber pembiayaan yang dapat diakses dan dimanfaatkan oleh petani di Desa Kedung Lengkong, Kecamatan Dlangu, Kabupaten Mojokerto, yaitu kredit pada koperasi dan juga kredit informal dari pedagang yang biasa mengajak kerjasama. Sumber pembiayaan informal merupakan sumber pembiyaan yang sangat familiar di lingkungan petani di daerah penelitian dengan para pedagang sebagai sumber pinjaman. Namun disisi lain, petani akan dirugikan dengan tingkat bunga yang tinggi serta akan mengikat petani untuk menjual hasil panen kepada pedagang yang memberikan pijaman. Berbeda dengan sumber informal yang dengan mudah dapat dimanfaatkan oleh petani, petani di daerah penelitian masih sedikit yang dapat mengakses sumber kredit formal dari koperasi.

Penelitian ini mengunakan analisis dengan regresi sederhana untuk memahami dampak ketersediaan kredit terhadap kesejahteraan petani. Hasil uji hipotesis adalah kredit berpengaruh positif terhadap kesejahtraan, dengan nilai koefisien regresi sebesar 0.291. Kredit membantu petani dalam pembelian pupuk, bibit dan hal-hal lain yang berkaitan dengan kebutuhan untuk usaha tani, sehinggan proses produksi pertanian dapat berjalan sesuai dengan perencanaan, sehingga hasil produksi sesuai dengan harapan petani sehingga memperbesar keuntungan. Keuntungan tersebut pada akhrinya menjadi sumber untuk memenuhi biaya-biaya dalam pemenuhan kebutuhan dasar. Kemampuan memenuhi kebutuhan tersebut mengangkat derajat hidup dan kesejahtraan masyarakat, sehingga masyarakat dapat memiliki kualitas hidup yang lebih baik.

Dan hal tersebut sesuai dengan beberapa hasil penelitian menunjukkan ketersediaan kredit memberi kesempatan bagi petani untuk membeli input atau modal lainnya (Adebayo et al. 2008; Nwaru et al. 2011; Saleem 2011; Rosmiati, 2012), yang pada akhirnya akan meningkatkan produksi dan pendapatan (Yehuala, 2008; Saboor et al. 2009; Sumelius et al. 2011; Ibrahim dan Bauer, 2013).

\section{KESIMPULAN}

Hasil penelitian dapat disimpulkan bahwa analisis faktor-faktor yang mempengaruhi akses petani petani di Desa Kedung Lengkong, Kecamatan Dlangu, Kabupaten Mojokerto terhadap sumber pembiayaan koperasi formal tergantung peran koperasi peran koperasi itu sendiri sehingga dapat meningkatkan peluang petani untuk memperoleh kredit. dari koperasi koperasi tersebut. Artinya koperasi sebagai pemberi kredit harus bekerja keras untuk aktif mengunjungi petani, memberi tahu tentang pengajuan pinjaman, dan juga dapat memberikan pinjaman langsung kepada petani.

Kredit memiliki dampak yang signifikan terhadap peningkatan kesejahteraan petani petani di Desa Kedung Lengkong, Kecamatan Dlangu, Kabupaten Mojokerto. Dengan peningkatan kesejahteraan, seseorang dapat mempertahankan kekuatan fisik untuk bekerja, sehingga meningkatkan produksi. Peningkatan jumlah kredit juga akan meningkatkan penyediaan dana bagi petani, sehingga meningkatkan konsumsi pangan anggota keluarga. Peningkatan produksi langsung dan konsumsi pangan pada akhirnya akan meningkatkan pendapatan yang juga akan meningkatkan kesejahteraan petani.

\section{UCAPAN TERIMA KASIH}

Ucapan terima kasih Kami Sampaikan Kepada Petani atau Kelompok Tani Desa Kedung Lengkong Kecamatan Dlanggu Kabupaten Mojokerto untuk waktu dan kerjasamanya dalam perolehan data Usaha Tani dan Analisa Kredit hasil penelitian ini untuk digunakan sebagai penunjang sumber pendanaan (Kredit Usaha Tani) sebagai peningkatan kesejahteraan Petani, serta. pihak lain yang membantu terselesaikannya penulisan paper serta, Pernyataan terimakasih yang ditujukan pada Universitas Wijaya Putra lembaga yang memberikan bantuan selama penelitian ini berlangsung.

\section{DAFTAR PUSTAKA}

Anggraeni, O. (2011). Penilaian tingkat kesehatan bank dengan menggunakan metode CAMEL Pada PT. Bank Pembangunan Daerah Jawa Tengah Tahun 2006-2009. Jurnal Telaah \& Riset Akuntansi, 3(1), 1-40.

E. Saqib, S., Kuwornu, J. K. M., Panezia, S., \& Ali, U. (2018). Factors determining subsistence farmers' access to agricultural credit in flood-prone areas of Pakistan. Kasetsart Journal of Social Sciences, 39(2), 262268. https://doi.org/10.1016/j.kjss.2017.06.001.

Ibrahim, A. H., \& Bauer, S. (2013). Access to microfinance and its impact on farm profits among rural farmers in Dryland of Sudan. Global Advanced Research Journal of Agricultural Sciences, 2(3), 88-102.

Isaga, N. (2018). Access to bank credit by smallholder farmers in Tanzania: a case study. Afrika Focus, 31(1), 241-256. https://doi.org/10.21825/af.v31i1.9048 
Islam, K. M. Z., Sipiläinen, T., \& Sumelius, J. (2011). Influence of credit constraints on technical, allocative and cost efficiency in peasant farming in Bangladesh. European Journal of Scientific Research, 56(2), 229243.

Nwaru, J. . (2011). Determinants of Informal Credit Demand and Supply among Food Crop Farmers in Akwa Ibom State , Nigeria. Journal of Rural and Community Development, 6(1), 129-139.

Römer, U., Weber, R., \& Musshoff, O. (n.d.). The Potential of Management Information System Data for the Development of Credit Scoring Models in Microfinance. 1-19.

Rosmiati, mia. (2012). Pengaruh Kredit Terhadap Perilaku Ekonomi Rumahtangga Petani Padi Sawah:Aplikasi Model Ekonomi Rumahtangga Usahatani. Journal of Technology Management, 11(2).

Rosmiati, E. (2012). Koperasi Sebagai Implementasi Ekonomi Kerakyatan. Widya, 29(320), 41-46.

Weber, R., \& Musshoff, O. (2012). Microfinance for agricultural firms - What can we learn from bank data? International Association of Agricultural Economists (IAAE) Triennial Conference. 